\title{
NUTRIENT INTAKE AND NUTRITIONAL STATUS OF THE AGED IN LOW INCOME AREAS OF SOUTHWEST, NIGERIA
}

\author{
W.A.O. Afolabi, I.O. Olayiwola, S.A. Sanni, O. Oyawoye
}

\begin{abstract}
Objective: The study was carried out to assess the nutrient intake and nutritional status of free living and noninstitutionalized elderly Nigerian men and women residing in low income areas. Design, Setting and Participants: The study was cross sectional involving 140 (58-99 years) apparently healthy elderly subjects randomly selected across four low income urban and rural areas of southwest Nigeria. Measurements: Data on socio economic characteristics and dietary intake (24-hour recall) were obtained with a structured questionnaire while anthropometric data were measured and nutritional status indices were classified using WHO standards. Nutrient intake data was compared to DRI while other data were analyzed using Statistical Package for Social Sciences version 16.0. Results: Majority (84.3\%) of the respondents were married and illiterate (80\%). Most popular occupation were farming $(47 \%)$ and trading $(35.7 \%)$. Half of the respondents earn $\leq$ NGN1, $000(\leq \mathrm{US} \$ 6)$ and only $27 \%$ earn $\geq$ N6000 (US\$37) monthly. The mean weight, height and arm circumference for men were $59.7 \pm 6.50 \mathrm{~kg}, 1.61 \pm 10.564 \mathrm{~m}$ and $27.5 \pm 9.24 \mathrm{~cm}$ respectively while that for women were $56.3 \pm 5.72 \mathrm{~kg}, 1.57 \pm 4.37 \mathrm{~m}$ and $27.0 \pm 5.22 \mathrm{~cm}$ respectively. The mean daily energy $(1805.2 \mathrm{Kcal})$ and protein $(23 \mathrm{~g})$ intake of women were significantly $(\mathrm{p}<0.05)$ lower than that of men $(2044 \mathrm{Kcal}$ and $27.7 \mathrm{~g}$ respectively). Intake of protein, calcium, riboflavin, niacin and vitamin C for both men and women were below DRI while iron, phosphorus, thiamine and energy intakes were adequate. Prevalence of underweight was low (2.9\%) in this study while that overweight (pre obesity) was high (20\% for men and $22.8 \%$ for women). Weight and BMI are significantly influenced by energy intake of the men $(r=0.439, p=0.008) ;(r=0.352, p=0.038)$ and not women $(r=0.229, p=0.186 ; r=0.320$, $p=0.06$ respectively) while arm circumference was significantly $(\mathrm{p}<0.05)$ influenced by protein intake of both men and women $(r=0.333, p=0.04$ and $r=0.404, p=0.02)$ respectively. Conclusion: This study has established a less than adequate intake of protein and some micronutrients among the elderly population as well as a high prevalence of overweight which coexists with underweight. There is need for a functional policy on the care of the aged in Nigeria in order to improve their nutrition, health and general wellbeing.
\end{abstract}

Key words: Nigerian, elderly, nutritional status, nutrient intake.

\section{Introduction}

Malnutrition is a great hazard to which the aged appears to be more vulnerable than the younger age groups due to problems relating to ignorance on appropriate food choices, loneliness, social isolation which often times lead to depression, apathy, lack of appetite, physical disabilities, cardiovascular problems and poverty among others. According to World Health Organisation (WHO) (1) the elderly are defined as persons above the age of 60 years with women comprising a majority of this population. The elderly population in the recent decade especially in Africa and other developing countries appear to be increasing (2-6). Govender (7) noted that the elderly are the gemstones of any society that are often ignored. Their care and

Department of Nutrition and Dietetics, College of Food Science and Human Ecology, Federal University of Agriculture, Abeokuta Ogun State Nigeria

Corresponding Author: W.A.O. Afolabi, Department of Nutrition and Dietetics, College of Food Science and Human Ecology, Federal University of Agriculture, Abeokuta Ogun State Nigeria, Email: afolabiwao@yahoo.com, Mobile: +234 803 4750655 wellbeing especially in rural communities depend largely on their children, relatives and sometimes government resources. This places a huge financial burden on their caregivers with a consequent lack in adequately providing for the nutritional and health needs of the aged in their care. Inadequate household food security, war and famine, and the indirect impact of HIV infection and AIDS among others have been documented as important determinants of poor nutritional status of elderly Africans (2). All these increases in the cost of living affects to a great extent dietary intakes and nutritional status of not only the general populace, but the often neglected elderly population. Furthermore, the vulnerability of the aged being far greater than that of the younger population shows the need for continuous monitoring of the aged with a view to identifying the extent of malnutrition among them in Nigeria. Several studies (8-10) have documented poor nutritional status among the aged. Similarly, previous studies $(5,7,11)$ have documented that the energy and nutrient intakes of the elderly were low compared to recommended dietary allowances. Older people are at nutritional risk, 
not only because of impaired digestion, absorption or utilization of nutrients associated with chronic disease or drug-nutrient interactions, but also due to an interaction between physiological, psychological and socioeconomic factors (11). In addition, it is evident that the elderly in developing countries will be vulnerable to health related predicaments associated with very low income, inadequate food intakes, poor food patterns, undernutrition, over-nutrition, chronic illness and diseases (12, $13,7)$.

In many developing countries including Nigeria, there is a dearth of information as well as epidemiological data on the nutritional status of the aged since studies regarding the nutrient intakes of these groups are limited and isolated. Studies on children particularly infants and preschool children appears to be more common than studies on the aged who are equally as vulnerable as young children to changes in social and economic conditions. In view of this, this study was carried out to assess the dietary habit, nutrient intake and nutritional status of the elderly who resides in low income areas of Ibadan in Southwest of Nigeria. It is expected that the study will further bridge the information gap and promote the care of the aged population.

\section{Methodology}

\section{Study area}

The study was carried out in Ibadan located in South West Nigeria. Ibadan is the capital of Oyo State and the third largest metropolitan area in Nigeria apart from Kano and Lagos. It has a population of 1,338,659 according to Nigeria Census (14). Ibadan metropolitan area is made up of eleven Local Government Areas with 5 in the urban area of the city and 6 in the periurban area of the city. However, Ibadan is inhabited by several ethnic groups in Nigeria but the Yorubas are the predominant ethnic group and are of middle and low socio economic class. Ibadan has a population pyramid similar to the national population pyramid of Nigeria hence was judged to have similar proportion of elderly put at $2.7 \%$ (15). According to the 2006 Census figure the population of Ibadan South East was 266,046 and Egbeda $(319,388)$ respectively $(16)$.

\section{Study Design}

This study was cross sectional and descriptive in nature and involved apparently healthy free living non institutionalized elderly Nigerians residing in low income areas of Oyo state Nigeria.

\section{Sample size and Sampling procedure}

A multistage sampling technique was used for the re search. First stage involved purposive selection of the three local government areas. Then using classification criteria for low income, high population density areas (17-21). The identification of the low income areas was further limited to an area within the selected areas that had majority (over 60\%) of its housing structure as urban slums (no decent roofing and houses built with mud) and with little or no access to basic facilities such as clinics, schools, and water and toilet facilities. An estimated $2.7 \%$ of the total population of each of the local government areas was assumed to be aged. Household listing was conducted for all the households with at least one aged male or female within the defined low income areas. Participants in the study were then selected systematically from a list of pre listed households using a sampling interval of five. Then one hundred and thirty two households were randomly selected where at most two participants were selected from a household.

A total of 140 free living and non-institutionalized and willing aged persons participated in the study. They were selected from the five identified low income urban communities (Aliwo, Gbenla, Kobomoje, Oke Paadi) and a rural community (Osegere) in the outskirts of Ibadan. The study comprised of both males and female in the ratio 1:1. The elderly start up age in this study was reduced to 58 years due to lower life expectancy for men and women in Nigeria compared to other developed countries (22) and the fact that most of the participants have no record of age or birth certificate and the ages were based on estimates using historical events. The Criteria for selection were based on the fact that the subject must be resident in the area and not a visitor, then he/she must have lived in the area for not less than 3-5 years prior to the study.

\section{Ethical Approval and Consent}

This study was approved by the ethical review and research committee of the College of Food Science and Human Ecology, Federal University of Agriculture, Abeokuta, Ogun state, Nigeria (Ref 2011/ COLFHEC/043). The subjects were also duly informed and verbal consent of the participants and their children was obtained before they were allowed to participate in the study.

\section{Method of Data Collection}

A structured pretested interviewer administered questionnaire was used to obtain information in this study. The questionnaire contained sections seeking the following information

i. Socio demographic and economic data

ii. Dietary recall (24-hour)

iii.Anthropometric data 


\section{Dietary recall}

With the aid of 24-hour dietary recall format, the respondents were asked to recall all foods and drinks including in-between meals consumed within the previous 24 hours. The source, time of consumption and estimated cost of each meal was also obtained. Other caregivers within the households especially children of the aged assisted in providing information on portion sizes and food description were confirmed with the aid of food models and household measures and were converted to grams using weighing scales before leaving the households. The nutrient intakes of the individual subjects were then calculated using a combination of Food Composition tables compiled by FAO (15) and Oguntona and Akinyele (24).

\section{Anthropometric data}

Anthropometric measurement collected includes weight, height and upper arm circumference. The weight of the subjects was measured while standing with both arms by the side and with only light clothing on. The pointer of the weighing scale (Hanson model) was adjusted to zero before each weighing and was recorded to the nearest $0.1 \mathrm{~kg}$

In measuring the height of the respondents, a locally constructed but standardized height meter was placed behind the heels of each subject and the height was measured while each individual was standing with the head fixed against the height meter and the level just above the hair was marked and recorded to the nearest $0.1 \mathrm{~cm}$.

The upper arm circumference was recorded as a measure to reflect protein and fat intake adequacy. The mid upper arm circumference was taken using WHO procedures (23). This was measured using a non stretchable tape measure. The measurement was taken in centimeters with the non elastic tape measure placed firmly on the left mid upper arm, at the midpoint between the acromion process of the scapular and the olecranon process of the ulna bone and compared to standards by Jellife (25).

The body mass index of the aged were calculated as weight of each individual in $\mathrm{kg}$ divided by the square of the height in metres, values were then compared to WHO (26) reference standards.

\section{Method of Data Analysis}

Statistical Package for Social Sciences Software (27) was used to analyze data obtained from questionnaire and represented as frequencies, percentages, means and Standard deviations. linear regression analyses (Bivariate) were also carried out to establish relationships and measure the effect of variations between variables after adjusting for age (protein and energy intakes were used as the dependent variables). Level of significance was defined at 95\% confidence interval $(p<0.05)$. Adequacy of nutrient intakes was compared with Dietary Reference intakes (DRI) (28).

\section{Results}

The socio economic and demographic characteristics of respondents are presented in table 1. Most (84.3\%) of the respondents were married while about $16 \%$ were widowed. Less than $20 \%$ of the respondents were educated and their major occupation was farming $(47.1 \%)$ and trading $(35.7 \%)$. Half of the respondents earn a monthly income $\leq 1000$ NGN $(<\mathrm{US} \$ 6)$. Fifty four percent of the houses were constructed with cement but most $(52.9 \%)$ of these houses had no toilet facilities and defecation is usually done in and around the houses in the urban low income areas and surrounding bushes in the rural area. Water is usually (100\%) sourced from a community stand pipe in the urban low income areas and a river located close to the rural community. Table 2 shows information on the mean anthropometric indices of the respondents. The men had slightly higher weight $(59.6 \mathrm{~kg})$, height $(161.4 \mathrm{~cm})$ and arm circumference $(27.5 \mathrm{~cm})$ compared to the women $(56.3 \mathrm{~kg}, 156.7 \mathrm{~cm}$, and $27.0 \mathrm{~cm}$ respectively). The body mass index of the women was slightly higher $(22.97 \mathrm{~kg} / \mathrm{m} 2)$ than that of the men $(22.77 \mathrm{~kg} / \mathrm{m} 2)$.

The usual feeding frequency per day for all the respondents was three times with breakfast customarily being consumed between 7:00-8:00 am, lunch at 1:30$2: 30 \mathrm{pm}$ and dinner between 7:30pm and 8:30 pm daily. The food of choice of these group of people for breakfast was 'hot maize porridge or pap' (eko) served with moinmoin (steamed bean pudding) or Akara (fried bean paste). During lunch, amala (prepared from yam flour)/ lafun (cassava based) is preferred with either Ewedu (Cochorus olitorus), okro, vegetable-melon soup, bean soup (Gbegiri) and stew served with or without meat or fish while either eko/agidi and Akara or mashed beans and stew are the usual meals for dinner. Breakfast and dinner are usually purchased from food vendors by most $(80.3 \%$ and $87.1 \%)$ of the respondents while lunch is mostly prepared at home $(76.5 \%)$. The cost of breakfast and dinner for majority (94\%) of the aged in this study ranges NGN 100-150 per individual. Snacks or between meals is not common among this population and fruits are only consumed when they are in season.

About $74 \%$ of the women were within the normal range of BMI, $20 \%$ were overweight while $5.7 \%$ were underweight. Among the men, however, about $87 \%$ had healthy BMI range, $8.6 \%$ were overweight while only $2.9 \%$ were found to be underweight. Nutrient intake analysis shown in Table 5 indicated that the mean intake of energy (2044 Kcal/day) carbohydrate $(388.3 \mathrm{~g})$, protein $(27.7 \mathrm{~g})$ and fat $(42.2 \mathrm{~g})$ for men was significantly $(\mathrm{p}<0.05)$ 
Table 1

Socio Demographic and Economic Characteristics of Aged in Low income areas of Ibadan

\begin{tabular}{|c|c|c|}
\hline Variable & Frequency & Percentage \\
\hline \multicolumn{3}{|l|}{ Age (years) } \\
\hline $58-68$ & 76 & 54.3 \\
\hline $69-79$ & 44 & 31.4 \\
\hline $80-89$ & 12 & 8.6 \\
\hline $90-99$ & 8 & 5.7 \\
\hline \multicolumn{3}{|l|}{ Marital status } \\
\hline Married & 118 & 84.3 \\
\hline Widowed & 22 & 15.7 \\
\hline Separated & 0 & 0 \\
\hline \multicolumn{3}{|l|}{ Literacy rate } \\
\hline Illiterate & 112 & 80.0 \\
\hline 10 School certificate & 26 & 18.6 \\
\hline 20 School certificate & 2 & 1.4 \\
\hline \multicolumn{3}{|l|}{ Occupation } \\
\hline Farming & 66 & 47.1 \\
\hline Trading & 50 & 35.7 \\
\hline Craft work & 12 & 8.6 \\
\hline None & 12 & 8.6 \\
\hline \multicolumn{3}{|l|}{ Monthly Income from occupation } \\
\hline N 0-1000 & 70 & 50.0 \\
\hline N1001-6000 & 32 & 22.9 \\
\hline N6001 and above & 38 & 27.1 \\
\hline \multicolumn{3}{|l|}{ Housing Structure } \\
\hline Mud & 64 & 45.7 \\
\hline Cement & 76 & 54.3 \\
\hline \multicolumn{3}{|l|}{ Toilet type } \\
\hline Pit Latrine & 66 & 47.1 \\
\hline Water Cistern & 0 & 0 \\
\hline No structured toilet (bush) & 74 & 52.9 \\
\hline \multicolumn{3}{|l|}{ Source of water } \\
\hline Pipeborne water & 0 & 0 \\
\hline Community stand pipe* & 140 & 100 \\
\hline River* & 140 & 100 \\
\hline \multicolumn{3}{|l|}{ Source of meal } \\
\hline \multicolumn{3}{|l|}{ Breakfast } \\
\hline Food vendor & 112 & 80.0 \\
\hline Home prepared & 28 & 20.0 \\
\hline \multicolumn{3}{|l|}{ Lunch } \\
\hline Food Vendor & 33 & 23.6 \\
\hline Home prepared & 107 & 76.4 \\
\hline Dinner & & 87.1 \\
\hline Food vendor & 122 & 12.9 \\
\hline Home prepared & 18 & \\
\hline \multicolumn{3}{|l|}{ Cost of meal } \\
\hline NGN1-99.9 & 2 & 1.4 \\
\hline NGN 100-150 & 132 & 94.3 \\
\hline$>$ NGN150 & 6 & 4.3 \\
\hline
\end{tabular}

${ }^{*}$ Multiple response

higher than that of the women. Similarly intakes of micronutrients including phosphorus, iron, thiamine, riboflavin niacin and Vitamin $C$ were higher among the men than the women except for the intake of calcium which was higher in the women than men. In terms of recommended daily intakes, the intakes of energy and phosphorus were adequate for men while intakes of iron, carbohydrate and thiamine were far above the recommended intakes and the intakes of protein, fat, calcium, riboflavin, niacin and Vitamin $\mathrm{C}$ were below the DRI for the men. Among the women, the higher intake of calcium compared to the men did not translate into adequate intake as they consumed it in amounts far below recommended intakes. However, the intakes of energy and phosphorus among the women were adequate while that of carbohydrate, iron, and thiamine were above the recommended amounts, and the intakes of protein, fat, riboflavin, niacin and vitamin $\mathrm{C}$ were below the recommended intakes. Energy intake was observed to significantly increase with BMI $(r=0.352$, $\mathrm{p}=0.038$ ) (table 7) among the men, this accounts for about $10 \%$ increase in BMI while $90 \%$ is accounted for by other factors. Similarly, energy intake also increased with weight and arm circumference. Linear regression coefficients of determination (adjusted R2) after adjusting for age indicates that energy intake influences almost $17 \%$ increase in weight for the men while it accounts for only $11.7 \%$ variation in arm circumference. Age did not influence either energy or protein intakes among the men and women. Furthermore, protein intakes were also significantly $(\mathrm{p}<0.05)$ associated with variations in weight, BMI and arm circumference for men accounting for approximately $25 \%$ and $16 \%$ variation in weight and BMI and only $9 \%$ for arm circumference of men. Among the women no significant relationship exists between energy intake, weight, and BMI and arm circumference. However, their arm circumference, weight and BMI were significantly influenced by their protein intake. Their protein intake similarly accounted for $13.2 \%, 12.7 \%$ and $13.8 \%$ variations in weight, BMI, and arm circumference respectively.

\section{Discussion}

This present study assessed the nutrient intake and nutritional status of free living, non-institutionalized elderly men and women in some low income urban and rural communities in Southwest Nigeria. More than half of the participants in this study were less than 68 years, this may be partly due to poor survival capacities among this population entrenched in the extent of poverty in the country, this suggests that only a very few proportion of elderly Nigerians live till age 80 years and above. The women were older compared to the men in this study. The men were taller than the women and this is similar to the findings among the elderly in Asaba, Delta state in South-South (29) Nigeria as well as in southwest Nigeria (30). However, the men weighed more than the women contrary to the reports of Odenigbo et al. (29) among similar populations but different ethnic group. We observed a significantly decreasing pattern of height and arm circumference with age among the women compared to the men who had these trends increasing with age but not statistically significant. This may be due to the fact that majority of the men were still engaged in farming and reasonably engaged in a vocation involving regular muscular exercise. A similar trend was also reported 
Table 2

Mean anthropometric indices of aged in low income areas of Ibadan by sex

\begin{tabular}{|c|c|c|c|c|}
\hline & Weight (kg) & Height $(\mathrm{cm})$ & Arm Circumference (cm) & $\mathrm{BMI} \mathrm{Kg} / \mathrm{m}^{2}$ \\
\hline Male & $59.6 \pm 6.500$ & $161.4 \pm 10.564$ & $27.5 \pm 2.918$ & $22.8 \pm 2.357$ \\
\hline Female & $56.3 \pm 5.723$ & $156.7 \pm 4.367$ & $27.0 \pm 3.000$ & $23.0 \pm 2.491$ \\
\hline
\end{tabular}

Table 3

Mid Upper Arm Circumference Evaluation of the Aged in Southwest Nigeria

\begin{tabular}{|c|c|c|c|c|c|}
\hline$\%$ standard & Level of Nutrition & Male & Female & Total & $\%$ Total \\
\hline$\geq 90$ & Acceptable & 46 & 48 & 94 & 67.1 \\
\hline $80 \%$ & Mild under-nutrition & 22 & 18 & 40 & 28.6 \\
\hline $70 \%$ & Moderate under-nutrition & 2 & 4 & 6 & 4.3 \\
\hline$<60$ & Severe under-nutrition & 0 & 0 & 0 & 0 \\
\hline
\end{tabular}

Table 4

Nutritional Status of the aged in low income areas by BMI

\begin{tabular}{|c|c|c|c|c|}
\hline \multirow{2}{*}{ Classification } & \multicolumn{2}{|c|}{ Men } & \multicolumn{2}{|c|}{ Women } \\
\hline & Frequency & Percent & Frequency & Percent \\
\hline Underweight & 2 & 2.9 & 4 & 5.7 \\
\hline Normal & 61 & 87.1 & 52 & 74.3 \\
\hline Overweight & 6 & 8.6 & 14 & 20.0 \\
\hline Obese & 0 & 0 & 0 & 0 \\
\hline
\end{tabular}

Table 5

Average Daily Nutrient intake of the Aged in Low income Areas of Nigeria

\begin{tabular}{|c|c|c|c|c|c|c|c|c|c|c|c|}
\hline & $\begin{array}{l}\text { Energy } \\
\text { (Kcal) }\end{array}$ & $\mathrm{CHO}(\mathrm{g})$ & Protein $(\mathrm{g})$ & Fat (g) & $\begin{array}{l}\text { Calcium } \\
(\mathrm{mg})\end{array}$ & $\begin{array}{l}\text { Phosphorus } \\
\text { (mg) }\end{array}$ & Iron (mg) & $\begin{array}{l}\text { Thiamine } \\
\text { (mg) }\end{array}$ & $\begin{array}{l}\text { Riboflavin } \\
\text { (mg) }\end{array}$ & Niacin (mg) & $\begin{array}{l}\text { Vitamin C } \\
(\mathrm{mg})\end{array}$ \\
\hline Men & 2044 & 388.3 & 27.7 & 42.2 & 568.9 & 684.9 & 20.9 & 1.2 & 0.7 & 8.8 & 24.6 \\
\hline$\%$ DRI & 97.2 & 298.3 & 49.5 & 72.8 & 47.4 & 97.8 & 261.3 & 100 & 53.9 & 55.0 & 27.3 \\
\hline Women & 1805.2 & 353.1 & 23.0 & 33.4 & 653.7 & 674.1 & 20.1 & 1.2 & 0.7 & 8.9 & 17.5 \\
\hline$\%$ DRI & 100.3 & 271.6 & 50.0 & 66.8 & 54.5 & 96.3 & 251.3 & 109 & 63.6 & 63.6 & 23.3 \\
\hline Sig(2-tailed) & $0.014^{*}$ & $0.00^{*}$ & $0.049^{*}$ & 0.092 & $0.021^{*}$ & 0.785 & 0.816 & 0.962 & 0.897 & 0.775 & 0.056 \\
\hline
\end{tabular}

${ }^{*}$ Statistically significant at $95 \% \mathrm{CI}$

among elderly Nigerians (29). Among the elderly population in this study, height, arm circumference and weight increased with BMI. Body weight also decreased with age among the women, this finding is similar to that of Suraih et al., (31) which reported that decline in body weight among women was greater than that of the men this may be associated with reduction in body water and muscle mass $(6,32)$ as well as social, health care, personal morbidity, availability and accessibility issues. Similar to the findings of Seong et al. (6), we found that the BMI of men decreased with age; this should not be interpreted as due to the ageing process but selective survival, they further affirmed that people with lower BMI tend to survive with increasing age thus shifting the BMI distribution of survivors downwards (33). The mid upper arm circumference (MUAC) were measured to reflect risk of malnutrition in this study, MUAC has been documented to be a more sensitive index than BMI in revealing under-nutrition among the elderly $(2,34)$. We observed that the arm circumference of the elderly in this study was strongly related to their BMI. Although majority of the elderly in this study appeared to have MUAC $\geq 80$ th percentile, the fact that a low proportion of under-nutrition exists among them still emphasizes the need for close monitoring and care of the aged. The level of under-nutrition in this study (using $<22 \mathrm{~cm}$ for women and $23 \mathrm{~cm}$ for men as cutoff points) by MUAC was $4.3 \%$ while by BMI it was $5.7 \%$. Mid upper arm circumference has been shown to be influenced by protein and fat intakes of individuals. In general, the nutrient intakes of both men and women in this study were low compared to DRI except for the intakes of energy for the women. The pattern of dietary intake of the elderly in this study supports the findings of a similar study in Ibadan southwest Nigeria (35) where the dishes were mostly dominated by cassava products (eba and amala), cereals (rice), legumes by beans (Akara or moi moi) and tubers (yam eaten boiled or pounded). The foods consumed by the elderly in this study were mostly from plant based sources and animal based foods are only consumed when they have economic access to it. This may be majorly responsible for the low protein and very high carbohydrate intakes among them. Intake of energy and protein appeared to increase with income in the study. Low intakes of protein results in malnutrition and thus increases susceptibility to infections whilst 
Table 6

Mean daily Energy and protein intake of the respondents by Income

\begin{tabular}{|c|c|c|c|}
\hline Frequency & Monthly income & Energy intake (Kcal) & Protein intake $(\mathrm{g})$ \\
\hline 70 & NGN 0-1000 (US\$6) & $1824 \pm 1.967$ & $26.4 \pm 0.987$ \\
\hline 32 & NGN1001-6000 (US\$6-35) & $2062 \pm 4.233$ & $30.1 \pm 1.354$ \\
\hline 38 & $\mathrm{NGN} \geq 6000$ & & \\
\hline$(\mathrm{US} \geq \$ 35)$ & $2520 \pm 3.213$ & $44 \pm 2.056$ & \\
\hline
\end{tabular}

NGN- Nigerian naira.

Table 7

Food habit of the Low income aged in Ibadan

\begin{tabular}{|c|c|c|c|}
\hline Meal & Usual time & Predominant dish & Average Estimated cost NGN \\
\hline Breakfast & 7:00-8:00 pm & Hot pap(eko) with moi moi or Akara & 135 (US\$0.79) \\
\hline Lunch & $1: 30-2: 30 \mathrm{pm}$ & $\begin{array}{l}\text { Amala/ Lafun with Ewedu/okro/vege- } \\
\text { table melon soup and stew served with } \\
\text { or without meat/fish }\end{array}$ & 150 (US \$0.88) \\
\hline Dinner & 7:30-8:30 pm & $\begin{array}{l}\text { Eko and Akara or mashed beans and } \\
\text { stew }\end{array}$ & 100 (US\$0.6) \\
\hline
\end{tabular}

Table 8

Relationship between Anthropometric Variables and Nutrient Intakes of the aged Men

\begin{tabular}{|c|c|c|c|}
\hline & pWeight & pBMI & pArm circumference \\
\hline \multicolumn{4}{|l|}{ Energy intake } \\
\hline $\mathrm{r}$ & 0.439 & 0.352 & 0.379 \\
\hline Adjusted r2 & 0.168 & 0.098 & 0.117 \\
\hline p-value & $0.008^{*}$ & $0.038^{*}$ & $0.025^{*}$ \\
\hline \multicolumn{4}{|l|}{ Protein intake } \\
\hline $\mathrm{r}$ & 0.519 & 0.426 & 0.333 \\
\hline "Adjusted r2 & 0.247 & 0.156 & 0.085 \\
\hline $\mathrm{p}$-value & $0.001^{*}$ & $0.011^{*}$ & $0.024^{*}$ \\
\hline
\end{tabular}

${ }^{*}$ statistically significant at 95\% confidence interval; $\mathrm{p}$ (All variables were adjusted for age.)

Table 9

Relationship between Anthropometric Variables and nutrient intakes of aged women

\begin{tabular}{llll}
\hline & pWeight & pBMI & pArm circumference \\
\hline Energy intake & & & 0.279 \\
$\mathrm{r}$ & 0.229 & 0.320 & 0.050 \\
Adjusted r2 & 0.024 & 0.075 & 0.105 \\
p- value & 0.186 & 0.060 & 0.404 \\
Protein intake & & & 0.138 \\
$\mathrm{r}$ & 0.397 & 0.391 & $0.016^{*}$ \\
Adjusted r2 & 0.132 & 0.127 & \\
p-value & $0.018^{*}$ & $0.020^{*}$ & \\
* $_{\text {statistically significant at 95\% confidence interval; p(All variables were adjusted for age.) }}$
\end{tabular}

*statistically significant at 95\% confidence interval; $\mathrm{p}$ (All variables were adjusted for age.)

infection is recognized to have a synergistic relationship with malnutrition (26). Fruits are consumed in lesser amounts compared to vegetables; they (fruits) are consumed only when they are in season while the reason for increased green vegetable consumption among the study group may be adduced to the fact that many south western Nigerian based dishes are often consumed with green vegetables (36). Corchorus. olitorus is usually recommended for pregnant women and nursing mothers due to its richness in iron (36-39). This may be responsible for the very high iron intakes among the subjects in this study. Reports of many studies $(3,5,39)$ suggest that older adults tend to have poor nutrient intakes. Although, energy and carbohydrate were the major macronutrients consumed in adequate amount in this study, protein and fat intake were low. Despite that the energy intake in this study exceeded $6.3 \mathrm{MJ}(1500 \mathrm{Kcal})$ which was argued to imply difficulty in meeting requirements for vitamins and minerals (40), the inability to meet the requirements for some vitamins and calcium in this study suggests that adequacy in energy intake does not imply adequate intakes of micronutrients. Ngatia et al. (41) documented very high carbohydrate intake among the elderly in Kenya, a similar study on the elderly in Zimbabwe (42) and India (43) documented very low protein intakes. Another study in south-south (44) and rural southwestern regions of Nigeria (45) documented very low intakes of thiamin, riboflavin and 
niacin among elderly populations; this is similar to the findings of this study where the intake of riboflavin and niacin were low.

In conclusion, this study has shown that the nutrient intake of the elderly is inadequate especially in protein and micronutrients which is a consequence of low intake of food of animal origin and fruits. The study also confirmed that mid upper arm circumference is a better index for assessment of under-nutrition among the elderly and is influenced strongly by their protein and energy intake. There is a heightened need to adequately improve their intakes through promoting appropriate dietary practices and increasing their access to food through community support.

Ethical Standards: This study was approved by the ethical review and research committee of the College of Food Science and Human Ecology, Federal university of Agriculture, Abeokuta, Ogun state, Nigeria (Ref 2011/COLFHEC/043) and all methods used comply with the research and ethical laws of the Federal Republic of Nigeria.

Conflicts of Interest: There was no funding received for this research. All authors declared no conflict of interest.

\section{References}

1. World Health Organisation. 2010a. Definition of an older or elderly person (online). Available http://www.who.int/healthinfo/survey/ ageingdefnolder/en/index.html (Accessed 15 April 2014)

2. Charlton Karen E. and Rose Donald 2001Nutrition among Older Adults in Africa: the Situation at the Beginning of the Millenium J. Nutr. 2001;vol. 131 no. 9 2424S-2428S

3. Olayiwola LM, Adeleye A, Jiboye AD. "Effect of Socio-cultural factors on Housing quality in Osogbo, Nigeria". International Symposium on Construction in Developing Economies: New issues and challenges. Santiago, Chile. 2006;January, 18-29.

4. National Population Commission. Statistical Information for the Nation. Federal Office of Statistics, Abuja, 1998.

5. Tucker K.L, Dallal G.E, Rush D. Dietary patterns of elderly Boston area residents defined by cluster analysis. J.Am Diet Assoc 1992;92(12):1487-1491

6. Seong Ting Chen, Hooi Jiun Ngoh \& Sakinah Harith. Prevalence of Malnutrition among Institutionalized Elderly People in Northern Peninsular Malaysia: Gender, Ethnicity and Age-specific Sains Malaysiana 2012;41(1) (141-148

7. Govender. Analysis of The Nutritional Status And Dietary Intake Data Of a group Of Elderly At A Day And Frail Care Centre In Verulam. Theses of Master of Technology Department of Food and Nutrition Consumer Science Faculty of Applied Sciences at the Durban University of Durban, South Africa, 2011.

8. Sanya E O, Kolo P M, Adekeye A, Ameh O I, Olanrewaju T O. Nutritional status of elderly people managed in a Nigerian tertiary hospital. Ann Afr Med [serial online] 2013 [cited 2014 Apr 15];12:140-1. Available from: http://www. annalsafrmed.org/text.asp? 2013/12/2/140/112416

9. Olayiwola IO1, Ketiku AO. Socio-demographic and Nutritional Assessment of the Elderly Yorubas in Nigeria. Asia Pac J Clin Nutr.;2006;15(1):95-101

10. Fadupin G.T. Social Support, Environmental Condition and Nutritional Status of the Elderly in Ibadan. Nigerian Journal of Nutritional Sciences, 2012;Vol 31, No 1., 2012

11. Charlton K E, Bourne Lesley T, Steyn Krisela and Laubscher Jacoba A. Poor nutritional status in older black South Africans Asia Pacific J Clin Nutr 2001;10(1): 31-38

12. World Health Organisation. 2009. Nutrition for older persons (online). Available http://www.who.int/nutrition/topics/ageing/en/index.html (Accessed 15 April 2014).

13. Oldewage-Theron, W.H., Dicks, E.G., Napier, C.E. and Rutengwe, R. Situation analysis of an informal settlement in the Vaal Triangle. Development Sothern Africa. 2005;22 (1): 13-26.

14. NPC. National Population Commission, Provisional Census Figure of the 2006 National Census for Oyo State, Nigeria 2006.

15. Food and Agricultural Organisation (1968) Food Composition Table for use in Africa. Available on http:/ /www.fao.org/docrep/003/x6877e/x6877e00.htm accessed 13th April, 2013.

16. Abumere S. Residential Differentiation in Ibadan: Some Sketches of an Explanation. In Filani M.O.; Akintola F.O.; and Ikporukpo C.O. (eds). Ibadan
Region, Rex Charles Publication Ibadan, 1994;pp.72-84

17. Asiyanbola, R.A., and Filani, M.O. An Exploratory Analysis of the Determinants of Women's Involvement in Housing Delivery in Nigeria. Research for Development. Published by the Nigerian Institute of Social and Economic Research, Ibadan, Nigeria. 2007;23( 1 and 2): 119-143

18. Ayeni, B. The Metropolitan Area of Ibadan, Its Growth and Structure. In: M.O. Filani, F.O. Akintola and C.O. Ikporukpo. Ibadan Region, Rex Charles Publication, Ibadan. 1994;p.34.

19. NISER. Socio-economic Survey of Ibadan City. Report of a Survey Commission by the Ibadan Metropolitan Planning Authority (IMPA), NISER, Ibadan. 1988;43pp

20. Okuneye, P., Adebayo, K., Opeolu, B. and Baddru, F. Analysis of the Interplay of Migration and Urban Expansion on Health and environment: the case of Lagos, Nigeria. 2007;28pp

21. Oyo State Government (2011) Detailed Information of the 33 Local Governments in Brief. http:/ / www.oyostate.gov.ng/ministries-departmentsand-agencies/local government-and-chieftaincy-matters/detailed-informationof-the-33-local-governments-in-brief/

22. WHO. Adults 60 years of age and older. In: physical status: the use and interpretation of anthropometry. Report of a WHO Expert committee, technical report series 1995;no. 854, ch. 9, Geneva:

23. Oguntona, E.B. and I.O. Akinyele. Nutrient Composting of Commonly Eaten Foods in Nigeria: Raw, Processed and Prepared. 1st Edn., Food Basket Foundation Publication Series, Ibadan, 1995.

24. Jelliffe D.B. The Assessment of Nutritional Status of the Community. WHO Monograph series 1966;No 53.

25. WHO. 2000 Turning the tide of malnutrition: responding to the challenge of the 21st century. Geneva: WHO, (WHO/NHD/00.7)

26. SPSS for windows. Release 16.0.0 SPSS Inc Standard Version

27. Food and Nutrition Board, Institute of Medicine. Dietary Reference Intakes Series, National Academy Press 2002. Available at www.nap.edu

28. Odenigbo U.M., Odenigbo C.U. and O.C. Oguejiofor. Nutritional Status of Elderly in Asaba, Delta State, Nigeria Pakistan Journal of Nutrition 2010;9 (5): 416-418,

29. Oguntona, C.R.B. and O. Kuku. Anthropometric survey of the elderly in southwestern Nigeria. Ann. Human Biol., 2000;27: 257-262.

30. Suriah, A.R., Zalifah M.K., Zainorni, M.J., Shafawi, S., Mimie Suraya, S., Zarina N. \& Wan Zainuddin W.A. Anthropometric measurements of the elderly. Malaysian Journal of Nutrition 1998;4: 55-63.

31. Nair, K.S. Aging muscle. American Journal of Clinical Nutrition 81(5): 953-963.

32. Lim TO, Ding LM, Zaki M, Suleiman AB, Fatimah S, Siti S, Tahir A \& Maimunah AH. Distribution of body weight, height and body mass index in a national sample of Malaysian adults. Med J Mal 2000;55(1):108-128.

33. Ismail, S. \& Manandhar, M. Anthropometric characteristics of older people in rural Malawi. Better nutrition for older people: assessment and Action HelpAge International and London School of Hygiene and Tropical Medicine London, UK, 1999.

34. Aromolaran, A.B. "The Nigeria Nutritional Problem: A case study of Ibadan and Selected Villages". M.Sc thesis, University of Ibadan, Ibadan, Nigeria, 1987.

35. Yekeen, T.A., Akintaro, O.I., Akinboro, A. and Azeez, M.A. (2013) Evaluation of cytogenotoxic and nutrient composition of three commonly consumed vegetables in South-Western Nigeria. The Free Library, http://www. thefreelibrary.com/Evaluation of cytogenotoxic and nutrient composition of three...-a0354661287 (Accessed April 30 2014)

36. Oyedele DJ, Asonugho C and OO Awotoye. Heavy metals in soil and accumulated by edible vegetable after phosphate fertilizer application. J. Environ. Agric. Food Chem. 2006;5(4): 1446-1453

37. Olaiya $\mathrm{C}$ and $\mathrm{J}$ Adebisi. Phyto-evaluation of the nutritional values of ten green leafy vegetables in South -Western Nigeria. The Internet Journal of Nutrition and Wellness. Volume 9 Number 2, 2009.

38. Mehta Pallavi., Patel Krishna, Chauhan Komal. Assessment of Diet, Nutrition \& Disease Profile of Elderly Females Residing in Rural Setting of Vadodara. Helpage India-Research \& Development Journal 2011;Vol. 17 No.1pg 5-14

39. Parfitt AM, Gallagher JC, Heaney RP, Johnston CC, Neer R, Whedon GD. Vitamin D and bone health in the elderly. Am J ClinNutr 1982;36: 1014-1031.

40. Ngatia, E.M., Gathece 1.W., Macigo F.G., Mulli T.K Mutara L.N., and Wagaiyu E.G. Nutritional And Oral Health Status of an Elderly Population In Nairobi East African Medical Journal 2008;Vol. 85 No. 8

41. Allain T. J., Wilson A.., Alfred Z., Gomo R., Donald J. Adamchak. Jonathon A. Matenga. Diet and nutritional status in elderly Zimbabweans Age and Ageing 1997;26: 463-470

42. Natarajan VS, Ravindran S, Sivashanmugam, Thyagarajan, Kailish K, Krishnaswamy B et al. Assessment of nutrient intake and associated factors in an Indian elderly population. Age Ageing; 1993;22: 103-8.

43. Nnanyelugo D. O., Kubiangha L. O. \& U. O. Akpanyung. Food intakes and pattern of consumption among elderly Nigerians with a low income. Ecology of Food and Nutrition Volume 8, Issue 2, 1979; pages 79-86 DOI:10.1080/03670 244.1979.9990548

44. Oguntona Clara R. B., Kuku Y. Olabisi \& Addo Adenike A. Dietary Survey of Rural Elderly in Nigeria Journal of Nutrition For the Elderly Volume 18, Issue 1, 1999; pages 1-14 DOI:10.1300/J052v18n01_01 